\title{
Correction to: Economy and Environment: How to Get What We Want
}

\author{
Carl B. Becker
}

\section{Correction to:}

\section{A. Sumi et al. (eds.), Adaptation and Mitigation Strategies for Climate Change, DOI 10.1007/978-4-431-99798-6_11}

The original version of chapter 11, "Economy and Environment: How to Get What We Want", was published in 2010 with exclusive rights reserved by the Publisher. It has now been converted to open access retrospectively and the copyright updated to The Author(s). It is licensed under the terms of the Creative Commons Attribution-NonCommercialNoDerivatives 4.0 International License. The book has also been updated with this change.

The updated version of this chapter can be found at https://doi.org/10.1007/978-4-431-99798-6_11 